Original Research

\title{
FDI Inflows, Market Fragmentation and Their Impact on Industrial Environmental Efficiency: An Empirical Study in China
}

\author{
Xiaoliang Zhou*, Xiangxiang Sun, Yuping Yang, Yanhua Chen \\ School of Economics and Management, Fuzhou University, Fuzhou, China
}

Received: 4 June 2019

Accepted: 26 August 2019

\begin{abstract}
Sustainable development of industry, especially in developing countries, is an effective way to solve the conflict between industrial economic growth and the ecological environment. Industrial environmental efficiency is selected to measure the sustainable development of industry. We used the super-SBM method to evaluate the industrial environmental efficiency of 29 provinces during the period of 2007-2015. Our study analyzes the effect of FDI and market fragmentation on industrial environmental efficiency based on the system GMM approach. The result indicates that the impact of FDI on industrial environmental efficiency is significantly negative, which suggests that FDI significantly hinders industrial environmental efficiency. Market fragmentation significantly inhibits industrial environmental efficiency. We also further investigate the effect of the interaction between FDI and market fragmentation on industrial environmental efficiency. The result indicates that the negative effect of FDI on industrial environmental efficiency is stronger in provinces with more severe market fragmentation. Based on the findings, the government should promote the integration of regional market, optimize the structure of FDI and improve environmental quality.
\end{abstract}

Keywords: FDI, market fragmentation, industrial environmental efficiency, super-SBM method, system GMM approach

\section{Introduction}

With the rapid development of industrialization and urbanization, environmental pollution caused by industrial development is becoming more and more serious. Industry is not only an important part of China's economic development, but also a source of

*e-mail: lisaxxiang@gmail.com high energy consumption and pollution. Although industrial added value accounted for $34 \%$ of GDP in 2015 , it consumes $65 \%$ of total energy consumption and produces about $68 \%$ of carbon dioxide in China. In fact, the essence of industrial pollution is the imbalance between industrial development and ecological environment. Under the pressure of environmental pollution and resource exhaustion, improving industrial sustainable development is an effective way to solve the conflict between industrial economic growth and ecology [1-3]. Industrial environmental efficiency refers to the environmental impact of unit value 
created by an industrial system, which reflects the desirable and undesirable outputs. Hence, industrial environmental efficiency is selected to measure the sustainable development of industry [1]. Meanwhile, under the background of capital flow globalization, a large amount of foreign direct investment flows into China. China's total foreign direct investment increased from $\$ 740652$ million in 2007 to $\$ 5124.07$ billion in 2016 (based on the China Statistical Yearbook), which makes it the third largest foreign direct investment inflow country after the United States and Britain. As a result, the relationship between FDI and environmental performance has been discussed. One view is that FDI can bring an advanced technology spillover effect to host countries and promote industrial structure upgrading and total factor productivity [4]. Another view is that FDI also brings environmental pollution to the host country. In order to attract FDI inflows, some local governments loosen environmental regulations and lower environmental standards, thus leading to the inflow of highly polluting industries into the developing countries and aggravating environmental degradation $[5,6]$. Therefore, FDI has both positive and negative impacts on the environment, which depends on the dominant channel [7]. Furthermore, whether there is another factor affecting the relationship between FDI and environmental efficiency deserves further discussion.

Market-oriented reform plays an important role in the achievements of China's economic development. The central government has taken many measures to realize the cross-regional flow of resources in the process of marketization. However, market-oriented reform fails to effectively improve the integrity of the domestic market [8]. China's domestic market is far less integrated. Market fragmentation is caused by local protection, administrative monopoly power and fiscal decentralization, which restricts the flow of factors and products to form intangible barriers and protect local industries, and reduces the efficiency of resource allocation. Resource allocation among provinces directly affects environmental performance $[9,10]$. Market fragmentation reduces the $R \& D$ investment, results in slow technological progress and environmental uncertainty, and inhibits environmental efficiency. In this study, we try to identify whether FDI has an impact on environmental efficiency through the path of market fragmentation.

Based on the above analysis, we analyzed the impact of FDI and market fragmentation on industrial environmental efficiency using the system GMM approach. Furthermore, we explore the effect of the interaction between FDI and market fragmentation on industrial environmental efficiency. Therefore, this study contributes to the existing literature in several aspects. First, few studies have been made on the relationship between market fragmentation and industrial environmental efficiency. Previous studies have considered only the relationship between market fragmentation and pollution emissions. To fill in this gap, we examined the effect of market fragmentation on industrial environmental efficiency base on the system GMM method. Second, there are few studies on the impact of FDI and market fragmentation on environmental efficiency in the integrated framework. Previous studies focused only on the effect of FDI on the environment and neglected the effect of institutional factors on the relationship between FDI and sustainable development. Market fragmentation is the institutional factor leading to resources misallocation, inefficient technology and management, and diseconomies of scale, which will inevitably affect the relationship between FDI and sustainable development.

The structure of the study is organized as follows: Section 2 presents the literature review. Section 3 outlines the empirical method, variable measurement and data. Section 4 reports and discusses the empirical results. Section 5 concludes the conclusions and puts forward policy recommendations.

\section{Literature Review}

We divide the literature review into three parts, which include the relationship between FDI and industrial environmental efficiency, the relationship between market fragmentation and industrial environmental efficiency, and the effect of FDI and market fragmentation on industrial environmental efficiency.

\section{The Relationship between FDI and Industrial Environmental Efficiency}

Foreign direct investment indirectly affects the environment by influencing economic growth [11]. The impact of FDI inflow on economic growth has been confirmed in many studies. Frankel and Romer [12] propose that FDI not only promotes economic growth, but also affects environmental performance. However, there is no consensus on the impact of FDI inflow on the environment. FDI has both positive and negative impacts on the environment, which depends on the dominant channel [7]. Pao and Tsai [13] argue that there are three channels to the relationship between FDI and the environment: the pollution-halo hypothesis, the pollution haven hypothesis and the scale effect hypothesis. Some scholars believe that FDI inflows bring positive technology spillovers such as advanced production technology, management technology and marketing experience to the host country [14]. The innovation of clean technology through FDI inflow is conducive to improving the environmental quality of the host country [15]. Liu et al. [11] suggest that FDI inflow may directly hinder pollutant emissions, which may due to the funding and technology for environmental protection through FDI. Al-mulali and Tang [16] find that FDI inflow has a negative impact 
on carbon dioxide emissions in the long term. Mielnik and Goldemberg [17] prove that FDI inflow decreases the energy intensity, which is associated with the technological innovation brought by FDI. FDI inflow also promotes green technology to host countries and improves environmental quality in developing countries [13]. Zeng and Eastin [18] argue that the FDI inflows enhance environmental awareness in developing countries. Zhang and Zhang [19] identify the validity of EKC and suggest that the effect of FDI inflows on carbon emissions is positive.

Another view is that FDI inflow also brings environmental pollution to the host country. In order to attract FDI inflows, local governments loosen the environmental regulations and lower the environmental protection standards, thus leading to the inflow of highly polluting industries into the developing countries $[5,6$, 20]. That is to say, FDI reduces environmental quality, thus supporting the pollution-haven hypothesis. FDI inflows increase the capital stock of the host country and expand the production scale and economic scale of the host country, thus increasing the consumption of resources. The growth of output results in more pollutant emissions, increases environmental pressure in host countries and hinders the improvement of environmental efficiency. Shahbaz et al. [7] indicate that FDI has a significant positive impact on carbon dioxide emissions in France. Ren et al. [21] analyze the relationship between FDI and carbon dioxide emissions, and suggest that FDI inflow increases carbon dioxide emissions. Sbia et al. [22] find that FDI increases the green energy consumption and carbon dioxide emissions in UAE. Solarin et al. [23] suggest that FDI positively affects carbon dioxide emissions. Shahbaz et al. [7] prove that FDI aggravates environmental degradation and confirms the pollution haven hypothesis. Zhang and Zhou [24] and Jiang et al. [25] also report that FDI has a negative impact on carbon dioxide emissions based on the Chinese city-level data. Tang and Tan [26] prove that FDI inflow positively increases the carbon dioxide emissions in Vietnam. Sun et al. [27] find that foreign direct investment increases by $1 \%$, and carbon emissions increase by $0.058 \%$ based on the ARDL model.

\section{The Relationship between Market Fragmentation and Industrial Environmental Efficiency}

China's domestic market is far less integrated. Compared with developed market economies, China's fragmented market is controlled by officials [8]. The fiscal decentralization and promotion incentive mechanism have driven local governments to compete for benefits, which has led to market fragmentation and the non-integration of the domestic market [28]. Many studies have analyzed the relationship between market fragmentation and economic growth [29, 30], and confirm the efficiency losses caused by local protection and market fragmentation [8, 28]. Yang et al. [31] point out that market fragmentation reduces the quality of economic development. Regional energy market fragmentation may become an obstacle to economic growth. Zhang and Zhang [32] argue that market fragmentation distorts energy allocation. Energy trade barriers increase the transport costs for energydeficient regions to trade with other regions. Market fragmentation also increases incentives for low-level technologies to exploit resources in energy-deficient regions.

Market fragmentation hinders the free flow of factors and commodities, distorts the allocation of resources and inhibits the economic growth brought about by diseconomies of scale [33]. Lin and Chen [9] suggest that factor market distortion affected by government intervention hinders the promotion of green total factor productivity. The protection of local government reduces the willingness to invest in R\&D and technological innovation, leading to the slow development of green energy-saving technology [31]. Market fragmentation leads to inefficient technology and management, diseconomies of scale and misallocation of resources. It is believed that market distortions hinders the improvement of energy industry efficiency [10]. Chang et al. [34] argue that political power has an important impact on environmental protection, and government efficiency significantly affects energy efficiency. Market fragmentation leads to collusion between local governments and enterprises. Energy is a natural resource with state-owned attributes. Local governments have the right to initial allocation. Those politically connected enterprises are more likely to get preferential access at lower prices, while efficient enterprises fail to get enough energy allocation, which seriously reduces energy efficiency [35]. Therefore, market fragmentation decreases the R\&D investment, results in slow technological progress and environmental uncertainty, and inhibits environmental efficiency.

\section{The Effect of FDI and Market Fragmentation on Industrial Environmental Efficiency}

Few studies have explored the impact of FDI and market fragmentation on the environment. Market fragmentation restricts the flow of resources and factors in different regions, resulting in the invalid market price signal and distorting the optimal allocation of resources in the domestic market [33]. One of the reasons why local governments divide the market is to protect some local state-owned enterprises. In addition, local governments also protect local backward enterprises for the purpose of economic growth and employment stability [36]. These low-efficiency and high-pollution enterprises are difficult to eliminate, and are even still profitable. In order to obtain political promotion, local officials take the way of imitating economic development strategy to maximize their own interests, intervene in enterprise investment through subsidies, and ultimately lead to low-level duplication and industrial isomorphism. Most 
of these duplicate developments are heavy chemical industries with high energy consumption and pollution, which aggravates environmental pollution and resource waste [37].

\section{Methodology \\ Calculation of Industrial Environmental Efficiency}

We use industrial environmental efficiency to reflect sustainable industrial development. Many studies use a single indicator to measure environmental efficiency, such as energy intensity [38], pollution emissions [39] and so on. A single indicator fails to reflect the impact of economic output on the environment. Considering the industrial economic performance and undesirable outputs, this study uses the industrial environmental efficiency to examine the balance of industrial economy and environment in different regions. The DEA method is a radial model for input or output, but it does not consider non-radial relaxation and undesirable output [40]. Based on Gomez-Calvet et al. [41], we use the super-SBM model with the undesirable outputs to evaluate industrial environmental efficiency. We assume the production system within DMUs. Each unit (DMU) has three factors: inputs, desirable outputs and undesirable outputs. Each DMU makes use of $m$ input factors and produces $s_{1}$ desirable output and $s_{2}$ undesirable output. Three vectors are defined: $x \in R^{m}, y^{g} \in R^{S_{1}}$ and $y^{b} \in R^{S_{2}}$, and the matrices $X, Y^{g}$ and $Y^{b}$ are defined as follows:

$$
\begin{gathered}
X=\left[x_{1}, x_{2}, \ldots, x_{L}\right] \in R^{m \times L} \\
Y^{g}=\left[y_{1}^{g}, y_{2}^{g}, \ldots, y_{L}^{g}\right] \in R^{s_{1} \times L} \\
Y^{b}=\left[y_{1}^{b}, y_{2}^{b}, \ldots, y_{L}^{b}\right] \in R^{s_{2} \times L}
\end{gathered}
$$

Then the production possibility set (PPS) is defined as follows:

$$
\begin{gathered}
T=\left\{\left(x, y^{g}, y^{b}\right) \mid x \geq \sum_{j=1}^{L} \lambda_{j} x_{j}, 0 \leq y^{g} \leq \sum_{j=1}^{L} \lambda_{j} y_{j}^{g}, y^{b}\right. \\
\left.\geq \sum_{j=1}^{L} \lambda_{j} y_{j}^{b}, l \leq e \lambda \leq u, \lambda \geq 0\right\}
\end{gathered}
$$

...where $\lambda=\left(\lambda_{1}, \lambda_{2}, \ldots, \lambda_{L}\right)^{\prime} \in R_{+}{ }^{L}$ is a weight vector, $e=1,1, \ldots, 1) \in R_{+}{ }^{L}$.

Based on Tone [42], the SBM model dealing with undesirable outputs is described as follows:

$$
\beta=\min \frac{1-\frac{1}{m} \sum_{i=1}^{m} \frac{s_{i}^{-}}{x_{i 0}}}{1+\frac{1}{s_{1}+s_{2}}\left(\sum_{r=1}^{s_{1}} \frac{s_{r}^{g}}{y_{r 0}^{g}}+\sum_{t=1}^{s_{2}} \frac{s_{t}^{b}}{y_{t 0}^{b}}\right)}
$$

$$
\begin{gathered}
\text { s.t. } \quad x_{0}=X \lambda+s^{-} \\
y_{0}^{g}=Y^{g} \lambda-s^{g} \\
y_{0}^{b}=Y^{b} \lambda+s^{b} \\
s^{-} \geq 0, s^{g} \geq 0, s^{b} \geq 0, l \leq e \lambda \leq u, \lambda \geq 0
\end{gathered}
$$

...where the vector $s^{g} \in R_{+}^{S_{1}}$ represents the loss of desirable outputs, $s^{-} \in R_{+}{ }^{m}$ represents the slacks in inputs, and $s^{b} \in R_{+}^{S_{2}}$ represents the slack in undesirable outputs. The target function value of $\beta$ is the solution of the optimization, and its range of value is $0 \leq \beta \leq 1$. If $\beta=1, s^{-}=s^{b}=s^{g}=0$, it indicates that the evaluated decision-making unit is effective.

According to Charnes and Cooper [43], the above formulas are transformed into equivalent linear programming problems.

$$
\begin{gathered}
\beta^{*}=\min \left\{t+\frac{1}{m+s_{2}}\left(\sum_{i=1}^{m} \Upsilon_{i}+\sum_{k=1}^{s_{2}} \Omega_{k}\right)\right. \\
\text { s.t. } 1=t-\frac{1}{s_{1}}\left(\sum_{r=1}^{s_{1}} \Theta_{r}\right) \\
\sum_{j=1, \neq 0}^{L} x_{i j} \Lambda_{j}-x_{i o} \Upsilon_{i}-x_{i 0} t \leq 0,(i=1, \mathrm{~K}, m) \\
\sum_{j=1, \neq 0}^{L} y_{r j}^{g} \Lambda_{j}+y_{r 0}^{g} \Theta_{r}-y_{r 0}^{g} t \geq 0,\left(r=1, \mathrm{~K}, s_{1}\right) \\
\sum_{j=1, \neq 0}^{L} y_{k j}^{b} \Lambda_{j}-y_{k 0}^{b} \Omega_{k}-y_{k 0}^{b} t \geq 0,\left(k=1, \mathrm{~K}, s_{2}\right) \\
\Upsilon_{i} \geq 0\left(\forall_{i}\right), \Theta \geq 0\left(\forall_{r}\right), \Omega \geq 0\left(\forall_{k}\right) \\
\Lambda_{j} \geq 0, l t \leq e \Lambda \leq u t, \Lambda \geq 0, t>0
\end{gathered}
$$

...where $\Lambda_{j}=t \lambda, \Upsilon=t \phi, \Theta=t \varphi, \Omega=t \eta$, and $\beta^{*}$ is environmental efficiency measured by the super-SBM method taking undesirable outputs.

According to Yang and $\mathrm{Li}$ [1] and $\mathrm{Li}$ et al. [44], the input and output indicators from basic economic development and environmental pollution are used to accurately assess the industrial environmental efficiency. We chose labor, capital, energy consumption and water consumption as input indicators, with industrial value added as desirable output indicator, and sulfur dioxide emission and dioxide emissions as undesirable output indicators. 


\section{Estimation of Market Fragmentation}

Market fragmentation seriously hinders the crossregional flow of factors (such as labor, capital and energy) in the national market. There are five main methods to measure market fragmentation, which includes the production method [8], trade law method, price method, economic cycle method and market survey method. Based on the method proposed by Parsley and Wei [45], this study uses price indices of 9 commodities $^{1}$ to evaluate the market fragmentation index in China during the period of 2007-2015. The detailed calculation steps are as follows.

First, we construct a three-dimensional $(t \times i \times k)$ panel data covering year $(t)$, region $(i)$ and commodities $(k)$. Subsequently, we calculate the relative absolute value $\left(\left|\Delta Q_{i j t}^{k}\right|\right)$ of region $i$ and region $j$ in year $t$ of commodity $k$. The formula used is as follows.

$$
\Delta Q_{i j t}^{k}=\ln \left(p_{i t}^{k} / p_{i t-1}^{k}\right)-\ln \left(p_{j t}^{k} / p_{j t-1}^{k}\right)
$$

...where $\Delta Q_{i j t}^{k}$ is the fluctuation of the relative price of product $k$ at time $t$ between two provinces, $p$ is the actual price, $i$ and $j$ indicate two provinces, $t$ represents time periods, and $k$ indicates 9 categories of commodities in our study. Transportation costs are closely related to the difference in the price of the same goods between the two regions in an integrated market. Considering the relative stability of transport costs, the smaller the fluctuation of $\Delta Q^{k}{ }_{i j t}$, the more integrated the market between two provinces.

Due to market fragmentation, the price ratio of the two provinces shows the characteristics of fluctuating up and down. If the difference is greater than the transportation cost, the two regional markets will be more or less fragmented. The band of arbitrage is measured by the absolute value.

$$
\left|\Delta Q_{i j t}^{k}\right|=\left|\ln \left(p_{i t}^{k} / p_{i t-1}^{k}\right)-\ln \left(p_{j t}^{k} / p_{j t-1}^{k}\right)\right|
$$

The De-mean method is used to eliminate system errors caused by fixed effects associated with commodity heterogeneity. We assume that:

$$
\left|\Delta Q_{i j t}^{k}\right|=a^{k}+\varepsilon^{i j k}
$$

...where $a^{k}$ is the price change caused by the characteristics of product $k$, and $\varepsilon^{i j k}$ is related to economic relations between two provinces.

These commodities are food, tobacco and alcohol, clothing, shoes and hats, cultural office supplies, daily necessities, Chinese and Western medicine and medical and health care supplies, books, magazines and electronic publications, and fuel.

$$
q_{i j t}^{k}=\left|\Delta Q_{i j t}^{k}\right|-\left|\Delta \bar{Q}_{i j t}^{k}\right|=\left(a^{k}-a^{-k}\right)+\left(\varepsilon^{i j k}-\varepsilon^{-i j k}\right)
$$

$$
\operatorname{Var}\left(\mathrm{q}_{\mathrm{nt}}^{\mathrm{k}}\right)=\left(\sum_{\mathrm{i} \neq \mathrm{j}} \operatorname{Var}\left(\mathrm{q}_{\mathrm{ijt}}^{\mathrm{k}}\right)\right) / \mathrm{N}
$$

...where the variance $\operatorname{var}\left(q^{k}\right)$ reflects the all commodities price fluctuations, which is caused by market fragmentation between provinces $i$ and $j$ at time $t$, and connotes the market fragmentation between two regional markets. In order to ensure that the estimated coefficients in subsequent estimates are not too small, we multiply the estimated original market fragmentation index by 100 .

\section{Empirical Method}

This section provides the empirical method to discuss the impact of FDI and market fragmentation on industrial environmental efficiency. Considering that environmental performance and economic development may influence each other, there may be bilateral causality. At the same time, some influencing factors of environmental quality variables are inevitably neglected in the evaluation, and there may be endogenous bias in the evaluation. Therefore, the generalized method of moments (GMM) is employed to analyze the estimation model. Consequently, we consider it necessary to add the first-lagged industrial environmental efficiency to the model and construct a dynamic model to control the difference of the initial states of each province. Based on Lin and Chen [9], we estimate the dynamic model as follows:

$$
\begin{gathered}
\text { efficiency }_{i, t}=\lambda_{0}+\lambda_{1} \text { efficiency }_{i, t-1}+\lambda_{2} \text { fdi }_{i, t}+ \\
\lambda_{3} \text { segment }_{i, t}+X_{i t} T+\alpha_{i}+\varepsilon_{i t}
\end{gathered}
$$

This study focuses on the moderating effect of market fragmentation, and examines the influencing mechanism of market fragmentation on the impact of FDI on industrial environmental efficiency. To this end, the interaction between market fragmentation and FDI is added to Eq. (8), and the model is set as follows:

$$
\begin{aligned}
\text { efficiency }_{\mathrm{i}, \mathrm{t}}= & \alpha_{0}+\alpha_{1} \text { efficiency }_{\mathrm{i}, \mathrm{t}-1}+\alpha_{2} \mathrm{fdi}_{\mathrm{i}, \mathrm{t}}+\alpha_{3} \text { segment }_{\mathrm{i}, \mathrm{t}}+\alpha_{4} \mathrm{fdi}_{\mathrm{i}, \mathrm{t}} \\
& * \text { segment }_{\mathrm{i}, \mathrm{t}}+\mathrm{X}_{\mathrm{i}, \mathrm{t}} \mathrm{T}+\beta_{\mathrm{i}}+\varepsilon_{\mathrm{i}, \mathrm{t}}
\end{aligned}
$$

...where $i$ indexes province and $t$ indexes year; efficiecy ${ }_{i, t}$ measures the industrial environmental efficiency, which is a dependent variable; $f d i_{i, t}$ is the indicator of foreign direct investment; segment ${ }_{i, t}$ measures the intensity of market fragmentation; and $X$ are vectors of control variables that also affect industrial environmental efficiency. 
This study uses the system GMM estimator proposed by Blundell and Bond [46]. The GMM method has two advantages compared with the fixed effect and random effect estimation of panel data. First, the GMM method takes the lags of regressors as predefined explanatory variables to the dynamic model. Second, the GMM method can also deal with potential endogenous problems by introducing predefined and exogenous variables as system instruments [11]. The estimator combines in a system the equation in first-differences with an equation in levels [47]. Blundell and Bond [46] argue that adding the original equation to the system and using the additional moment condition significantly improve the efficiency and reduce the finite sample bias compared with the simple first-differenced GMM. We consider all regression variables as endogenous regression variables in the model, and test them by using their lag levels in differential equations and their lag differences in horizontal equations. We consider the year dummies and province dummies in all our regression models and instrument sets, and use Sargan statistics to assess the validity of the instruments.

The super-SBM model is employed to evaluate the industrial environmental efficiency of 29 provinces in China during the period of 2007-2015. According to Parsley and Wei [45], we used price indices of 9 commodities to calculate the market fragmentation based on Eq. (1)-(5). FDI is measured by the ratio of foreign direct investment to GDP. Industrial environmental efficiency is also affected by other factors. Economic development is closely related to technological innovation and energy consumption. Therefore, it must be included in the regression model. Per capita GDP is used to evaluate economic growth [1, 19], which captures economic development. Industrial structure affects the allocation and flow of resources, and also includes the distribution of heavy industrial enterprises, which affects environmental efficiency. The ratio of the output value of the tertiary industry to that of the secondary industry is a proxy for industrial structure, which is represented as industry. Human capital affects the application of new technologies and pollution emissions. Per capita average years of education are used to measure human capital (edu), which captures the quality of labor force. R\&D investment is closely related to the innovation and application of energy-saving technology. The ratio of R\&D investment to GDP is a proxy for technical progress, which is represented as R\&D. Environmental governance investment increases investment in environmental protection and provides subsidies for equipment renewal. The ratio of the environmental governance investment to GDP is employed to measure the environmental governance investment, which is represented as einvestment.

\section{Data and Descriptive Statistics}

All data are collected from the China Compendium of Statistics (1949-2008), the China Statistical Yearbook, the China Environmental Yearbook, the China Environmental Statistics Yearbook, the China Labor Statistics Yearbook, the China Population and Employment Statistics Yearbook, the China Industrial Science and Technology Statistical Yearbook and the China Energy Statistics Yearbook. Table 1 shows the summary statistics of key variables in 29 provinces during 2007-2015.

According to the market fragmentation index obtained above, Fig. 1 shows the average market fragmentation index of 29 provinces in China from 2007 to 2015. Based on the estimated results, there is a serious market fragmentation in China caused by local protection, administrative monopoly power and fiscal decentralization. We find that the lowest average market fragmentation is 0.1572 in Liaoning Province. Generally speaking, the average market fragmentation in the western region is higher than that in the eastern and central regions. These results indicate that market fragmentation still has great room for improvement.

This study calculated the regional industrial environmental efficiency from 2007 to 2015, which is shown in Fig. 2. The results show that the overall level of industrial environmental efficiency in China is relatively low, showing an upward trend in time.

Table 1. Statistical descriptions of main variables.

\begin{tabular}{|c|c|c|c|c|c|}
\hline Variable & $\mathrm{N}$ & Mean & Std Dev & Min & Max \\
\hline efficiency & 261 & 0.5031 & 0.2031 & 0.1530 & 1.0400 \\
\hline$f d i$ & 261 & 0.3475 & 0.2662 & 0.0108 & 1.2778 \\
\hline segment & 261 & 0.3321 & 0.2998 & 0.0013 & 1.9221 \\
\hline gdp & 261 & 10.4294 & 0.5461 & 8.8414 & 11.5895 \\
\hline industry & 261 & 1.2199 & 0.3148 & 0.2478 & 2.0119 \\
\hline edu & 261 & 8.7619 & 0.9570 & 6.7639 & 12.2813 \\
\hline einvestment & 261 & 1.4325 & 0.7515 & 0.0500 & 4.6600 \\
\hline R\&D & 261 & 0.1465 & 0.1045 & 0.0284 & 0.6013 \\
\hline
\end{tabular}




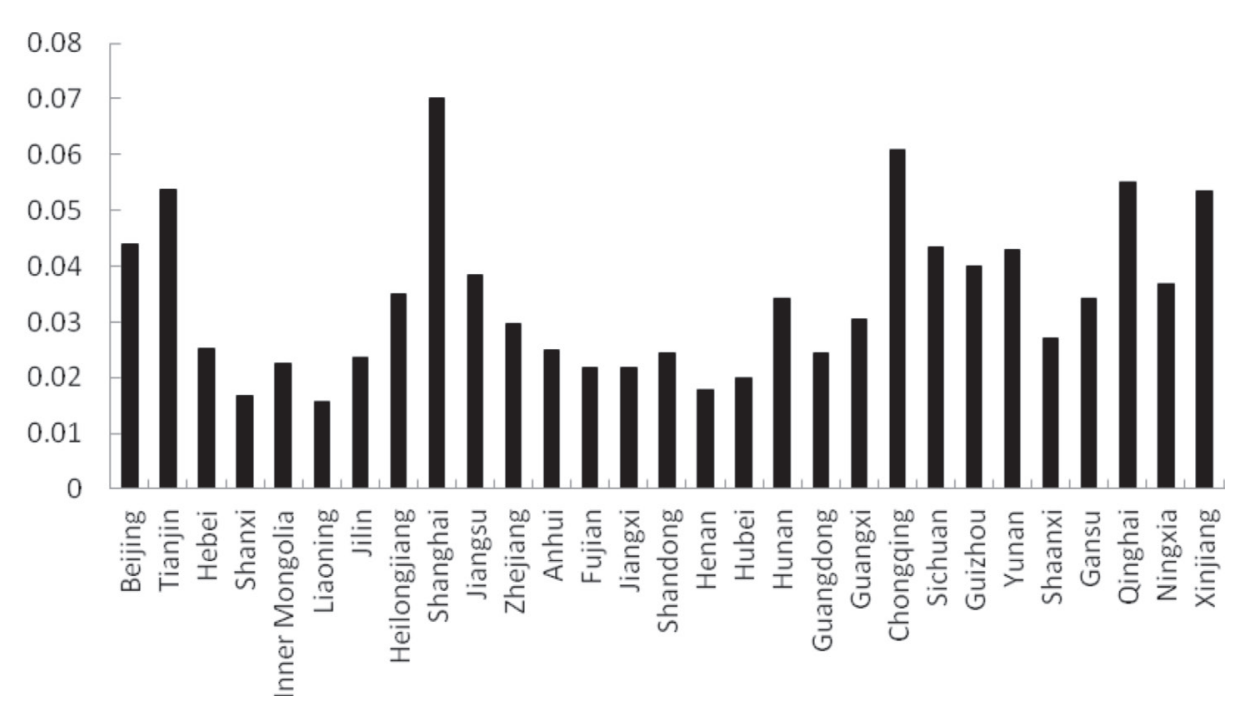

Fig. 1. Average of market fragmentation index of 29 provinces during 2007-2015.

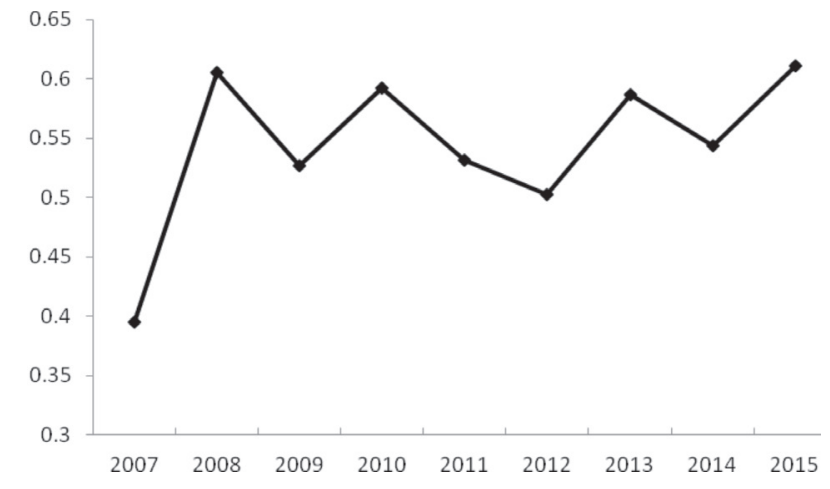

Fig. 2. Average of industrial environmental efficiency in China during 2007-2015.

\section{Empirical Results and Discussion}

\section{Preliminary Analysis Based on the Static Panel}

Based on the above research framework, we made a preliminary analysis to discuss the effect of explanatory factors, and provide a comparison for further analysis. Meanwhile, we chose the random effect model or fixed effect model according to the Hausman test. Table 2 displays the empirical results using the random effect model and fixed effect model.

According to Table 2, the coefficient of FDI is significantly negative in all models. Market fragmentation significantly hinders the improvement of industrial environmental efficiency, which is consistent with our expectation. The Hausman test indicates that the fixed effect model is more suitable for analysis compared to the random effect model. Therefore, we select the fixed effect model for further investigation in our study. In model (4), we observe that the coefficient of FDI is -0.2015 at the level of $5 \%$, which indicates that FDI has a significantly negative impact on industrial environmental efficiency. The coefficient of market fragmentation is -0.0573 at the level of $5 \%$, which demonstrates that market fragmentation significantly inhibits industrial environmental efficiency based on the fixed effect model.

\section{GMM Method of Dynamic Panel}

The first-lagged dependent variable is added to construct dynamic model in Eq. (1). However, the dynamic panels have weaknesses in endogenous problems. Dynamic panel endogeneity and excessive recognition of instrument variables are effectively solved by using the GMM method. Two tests are carried out before using the GMM model. First, the first- and second-order autocorrelation AR (1) and AR (2) of the perturbation term need to be confirmed. We also make sure that the null hypothesis has no residual correlation. Second, we continue to test whether the GMM model is over-recognition. The Sargan test is used to test the validity of variable estimation.

According to Table 3, the Wald test of all models is significant, which suggests that the regression results are significant. AR (1) and AR (2) suggest that the firstorder correlation is significant and that the second-order correlation is not significant, which is consistent with the requirement of the GMM method. The Sargan test indicates that all regression models do not reject the null hypothesis that the selected instrumental variables are valid, which indicates that the instrumental variables used in the estimation are reasonable and valid.

Table 3 shows the empirical results based on the system GMM method. We use the method of adding one control variable at a time to represent the results. According to Table 3, the regression coefficients of FDI are significantly negative in all models. The results confirm that FDI suppresses the improvement of industrial environmental efficiency. We also find that the coefficients of market fragmentation are significantly negative in all models, which indicate that market 
Table 2. Regression of market fragmentation on ecological efficiency by RE and FE models.

\begin{tabular}{|c|c|c|c|c|}
\hline & RE Model (1) & RE Model (2) & FE Model (3) & FE Model (4) \\
\hline$f d i$ & $\begin{array}{c}-0.2561 * * * \\
(-4.19)\end{array}$ & $\begin{array}{c}-0.2306^{* * * *} \\
(-3.54)\end{array}$ & $\begin{array}{c}-0.1830 * * \\
(-2.19)\end{array}$ & $\begin{array}{c}-0.2015^{* *} \\
(-2.42)\end{array}$ \\
\hline segment & $\begin{array}{c}-0.0749 * * \\
(-2.52)\end{array}$ & $\begin{array}{c}-0.0541 * \\
(-1.91)\end{array}$ & $\begin{array}{c}-0.0594 * * \\
(-1.98)\end{array}$ & $\begin{array}{c}-0.0573 * * \\
(-1.96)\end{array}$ \\
\hline$g d p$ & & $\begin{array}{c}0.0403 \\
(0.65)\end{array}$ & & $\begin{array}{c}-0.1002 \\
(-0.77)\end{array}$ \\
\hline industry & & $\begin{array}{c}0.1754 * * * \\
(3.36)\end{array}$ & & $\begin{array}{c}0.2315^{* * *} \\
(3.40)\end{array}$ \\
\hline$e d u$ & & $\begin{array}{c}0.0312 \\
(0.90)\end{array}$ & & $\begin{array}{c}0.0128 \\
(0.27)\end{array}$ \\
\hline einvestment & & $\begin{array}{c}-0.0115 \\
(-0.91)\end{array}$ & & $\begin{array}{c}-0.0112 \\
(-0.82)\end{array}$ \\
\hline$R \& D$ & & $\begin{array}{c}-0.8040 * * * \\
(-3.03)\end{array}$ & & $\begin{array}{c}-1.3922^{* *} \\
(-2.56)\end{array}$ \\
\hline constant & $\begin{array}{c}0.4337 * * * \\
(11.66)\end{array}$ & $\begin{array}{c}-0.3501 \\
(-0.71)\end{array}$ & $\begin{array}{c}0.4041 * * * \\
(11.03)\end{array}$ & $\begin{array}{l}1.1796 \\
(0.95)\end{array}$ \\
\hline time fixed effect & $\mathrm{Y}$ & $\mathrm{Y}$ & $\mathrm{Y}$ & Y \\
\hline region fixed effect & $\mathrm{Y}$ & $\mathrm{Y}$ & $\mathrm{Y}$ & $\mathrm{Y}$ \\
\hline sample size & 261 & 261 & 261 & 261 \\
\hline$R^{2}$ & 0.3753 & 0.4277 & 0.3779 & 0.4334 \\
\hline
\end{tabular}

Note: * indicates significance at the $10 \%$ level; ** indicates significance at the $5 \%$ level; *** indicates significance at the $1 \%$ level.

Table 3. Regression of market fragmentation on ecological efficiency based on GMM.

\begin{tabular}{|c|c|c|c|c|c|c|c|}
\hline & Model (1) & Model (2) & Model (3) & Model (4) & Model (5) & Model (6) & Model (7) \\
\hline$f d i$ & $\begin{array}{c}-0.3532 * * * \\
(-2.65)\end{array}$ & $\begin{array}{c}-0.3019 * * \\
(-2.09)\end{array}$ & $\begin{array}{c}-0.3114 * * \\
(-2.24)\end{array}$ & $\begin{array}{c}-0.3113^{* *} \\
(-2.25)\end{array}$ & $\begin{array}{c}-0.3078 * * \\
(-2.18)\end{array}$ & $\begin{array}{c}-0.2947 * * \\
(-2.04)\end{array}$ & $\begin{array}{c}-0.2709 * * \\
(-1.79)\end{array}$ \\
\hline segment & $\begin{array}{c}-0.0381 * \\
(1.70)\end{array}$ & $\begin{array}{c}-0.0950 * * * \\
(-3.29)\end{array}$ & $\begin{array}{c}-0.0955^{* * *} * \\
(-3.36)\end{array}$ & $\begin{array}{c}-0.0959 * * * \\
(-3.43)\end{array}$ & $\begin{array}{c}-0.0962 * * * \\
(-3.39)\end{array}$ & $\begin{array}{c}-0.0962 * * * \\
(-3.28)\end{array}$ & $\begin{array}{c}-0.0622 * * \\
(-2.25)\end{array}$ \\
\hline$g d p$ & & $\begin{array}{c}-0.0867^{*} \\
(-1.90)\end{array}$ & $\begin{array}{c}-0.0767 \\
(-1.39)\end{array}$ & $\begin{array}{c}-0.0734 \\
(-1.00)\end{array}$ & $\begin{array}{c}-0.0756 \\
(-1.03)\end{array}$ & $\begin{array}{c}-0.0652 \\
(-0.72)\end{array}$ & $\begin{array}{c}-0.0522 \\
(-0.58)\end{array}$ \\
\hline industry & & & $\begin{array}{c}0.0490 * \\
(1.72)\end{array}$ & $\begin{array}{c}0.0487 * \\
(1.76)\end{array}$ & $\begin{array}{c}0.0467^{*} \\
(1.85)\end{array}$ & $\begin{array}{c}0.0399 * \\
(1.75)\end{array}$ & $\begin{array}{c}0.0401^{* *} \\
(1.98)\end{array}$ \\
\hline$e d u$ & & & & $\begin{array}{c}-0.0026 \\
(-0.07)\end{array}$ & $\begin{array}{c}-0.0044 \\
(-0.11)\end{array}$ & $\begin{array}{c}-0.0041 \\
(-0.11)\end{array}$ & $\begin{array}{c}-0.0055 \\
(-0.15)\end{array}$ \\
\hline einvestment & & & & & $\begin{array}{c}0.0060^{*} \\
(1.74)\end{array}$ & $\begin{array}{c}0.0049^{*} \\
(1.79) \\
\end{array}$ & $\begin{array}{c}0.0020^{* *} \\
(2.13)\end{array}$ \\
\hline$R \& D$ & & & & & & $\begin{array}{c}-0.2187^{*} \\
(-1.73)\end{array}$ & $\begin{array}{c}-0.3461 * \\
(-1.79)\end{array}$ \\
\hline$f d i{ }^{*}$ segment & & & & & & & $\begin{array}{c}0.0939 * * \\
(2.09)\end{array}$ \\
\hline efficiency $_{t-1}$ & $\begin{array}{c}-0.3053 * * * \\
(-4.47) \\
\end{array}$ & $\begin{array}{c}-0.2896 * * * \\
(-4.71) \\
\end{array}$ & $\begin{array}{c}-0.2967 * * * \\
(-4.76) \\
\end{array}$ & $\begin{array}{c}-0.2966 * * * \\
(-4.75) \\
\end{array}$ & $\begin{array}{c}-0.2940 * * * \\
(-5.01)\end{array}$ & $\begin{array}{c}-0.2927^{* * *} \\
(-4.85) \\
\end{array}$ & $\begin{array}{c}-0.2929 * * * \\
(-4.82)\end{array}$ \\
\hline constant & $\begin{array}{c}0.8130^{* * * *} \\
(11.18)\end{array}$ & $\begin{array}{c}1.7179 * * * \\
(3.44)\end{array}$ & $\begin{array}{c}1.5597 * * \\
(2.37)\end{array}$ & $\begin{array}{c}1.5495^{* *} \\
(2.29)\end{array}$ & $\begin{array}{c}1.5795^{* *} \\
(2.32)\end{array}$ & $\begin{array}{c}1.5052 * * \\
(2.00)\end{array}$ & $\begin{array}{c}1.3984^{*} \\
(1.89)\end{array}$ \\
\hline sample size & 261 & 261 & 261 & 261 & 261 & 261 & 261 \\
\hline $\mathrm{AR}(1)$ & 0.0318 & 0.0343 & 0.0244 & 0.0208 & 0.0275 & 0.0362 & 0.0172 \\
\hline $\mathrm{AR}(2)$ & 0.5173 & 0.6939 & 0.4255 & 0.2389 & 0.3237 & 0.2353 & 0.2375 \\
\hline Sargan Value & 28.797 & 27.465 & 26.874 & 25.267 & 23.005 & 22.173 & 21.813 \\
\hline
\end{tabular}

Note: $*$ indicates significance at the $10 \%$ level; $* *$ indicates significance at the $5 \%$ level; $* * *$ indicates significance at the $1 \%$ level. 
Table 4. Robustness test for alternative measurement.

\begin{tabular}{|c|c|c|c|c|c|c|}
\hline & Model (1) & Model (2) & Model (3) & Model (4) & Model (5) & Model (6) \\
\hline$f d i$ & $\begin{array}{c}0.0835^{* * *} \\
(2.64)\end{array}$ & $\begin{array}{c}0.0839 * * \\
(2.39)\end{array}$ & $\begin{array}{c}0.0644 * * \\
(2.37)\end{array}$ & $\begin{array}{c}0.0590^{*} \\
(1.89)\end{array}$ & $\begin{array}{c}0.0634 * * \\
(2.17)\end{array}$ & $\begin{array}{c}0.0766^{* * *} \\
\quad(3.25)\end{array}$ \\
\hline segment & $\begin{array}{c}0.0260 * * * \\
(3.20)\end{array}$ & $\begin{array}{c}0.0250 * * * \\
(3.10)\end{array}$ & $\begin{array}{c}0.0235^{* * *} \\
(2.98)\end{array}$ & $\begin{array}{c}0.0236^{* * *} \\
(3.01)\end{array}$ & $\begin{array}{c}0.0225^{* * *} \\
(3.03)\end{array}$ & $\begin{array}{c}0.0246^{* * * *} \\
(2.89)\end{array}$ \\
\hline$g d p$ & & $\begin{array}{c}-0.0011 \\
(-0.13) \\
\end{array}$ & $\begin{array}{c}0.0107 \\
(0.99)\end{array}$ & $\begin{array}{c}-0.0020 \\
(-0.17)\end{array}$ & $\begin{array}{c}-0.0057 \\
(-0.45)\end{array}$ & $\begin{array}{c}-0.0006 \\
(-0.07)\end{array}$ \\
\hline industry & & & $\begin{array}{c}0.0434 * * * \\
(3.26)\end{array}$ & $\begin{array}{c}0.0460 * * * \\
(3.06)\end{array}$ & $\begin{array}{c}0.0459 * * * \\
(3.06)\end{array}$ & $\begin{array}{c}0.0348 * * \\
(2.17)\end{array}$ \\
\hline$e d u$ & & & & $\begin{array}{l}0.0106 \\
(0.89)\end{array}$ & $\begin{array}{c}0.0098 \\
(0.88)\end{array}$ & $\begin{array}{c}0.0154 \\
(1.34)\end{array}$ \\
\hline einvestment & & & & & $\begin{array}{c}0.0078^{*} \\
(1.73)\end{array}$ & $\begin{array}{c}0.0075^{*} \\
(1.76)\end{array}$ \\
\hline$R \& D$ & & & & & & $\begin{array}{c}-0.2585^{*} \\
(-1.71)\end{array}$ \\
\hline efficiency $_{t-1}$ & $\begin{array}{l}0.0260 \\
(0.37)\end{array}$ & $\begin{array}{c}0.0278 \\
(0.38)\end{array}$ & $\begin{array}{c}0.0303 \\
(0.48)\end{array}$ & $\begin{array}{c}0.0194 \\
(0.32)\end{array}$ & $\begin{array}{l}0.0273 \\
(0.40)\end{array}$ & $\begin{array}{c}0.0452 \\
(0.62)\end{array}$ \\
\hline constant & $\begin{array}{c}0.0295^{* * *} * \\
(3.67)\end{array}$ & $\begin{array}{c}0.0412 \\
(0.46)\end{array}$ & $\begin{array}{c}-0.1288 \\
(-1.04)\end{array}$ & $\begin{array}{c}-0.0897 \\
(-0.82)\end{array}$ & $\begin{array}{c}-0.0566 \\
(-0.55)\end{array}$ & $\begin{array}{c}-0.1135 \\
(-0.95)\end{array}$ \\
\hline sample size & 261 & 435 & 435 & 435 & 435 & 435 \\
\hline $\operatorname{AR}(1)$ & 0.0415 & 0.0223 & 0.0136 & 0.0365 & 0.0178 & 0.0102 \\
\hline $\mathrm{AR}(2)$ & 0.8622 & 0.7214 & 0.4875 & 0.4355 & 0.3167 & 0.4136 \\
\hline Sargan Value & 26.772 & 26.219 & 25.378 & 24.567 & 23.620 & 21.465 \\
\hline
\end{tabular}

Note: * indicates significance at the $10 \%$ level; ** indicates significance at the $5 \%$ level; *** indicates significance at the $1 \%$ level.

fragmentation inhibits the improvement of industrial environmental efficiency. In model (7), the interaction between FDI and market fragmentation is significantly positive, which indicates that market fragmentation improves the negative effect of FDI affecting industrial environmental efficiency.

\section{Discussion}

According to the empirical results, further discussion is carried out. Economic performance directly affects the promotion of local officials in China. In order to promote local economic growth, governments can loosen environmental regulations and lower environmental protection standards and entry barriers to attract foreign direct investment and encourage the inflow of highly polluting industries. Some multinational enterprises produce some highly polluting products, but they are not subject to administrative penalties because of low environmental regulations. Meanwhile, FDI inflows increase the capital stock, expand the production scale and promote the resource consumption and pollution emissions. Therefore, we believe that FDI has a negative impact on the improvement of industrial environmental efficiency.

Market fragmentation distorts the resource allocation and reduces the factor productivity. First, market fragmentation hinders the upgrading of industrial structure, which results in high pollution emissions. Market fragmentation caused by the local protectionism breaks down production activities based on comparative advantages in different regions, resulting in slow upgrading of industrial structure. Second, R\&D investment is the key to technological progress. Market fragmentation reduces the willingness to increase R\&D investment, which slows down the green and clean production technology and increases pollution emissions. Third, enterprises use excessive resources for rent-seeking to maintain monopoly behavior, resulting in distortion and waste of resource allocation. Therefore, market fragmentation inhibits the industrial environmental efficiency.

Market fragmentation leads to resource misallocation, reduces the efficiency of factor allocation, hinders the promotion of technological innovation, and further affects the ability and motivation of domestic enterprises to obtain FDI technology spillover effect. Market fragmentation hinders the formation of the domestic competition mechanism, weakens the competitiveness of domestic enterprises and leads to more multinational companies entering the host country through the FDI to compete for market share. In the regions with low market fragmentation, FDI is interfered with by less government intervention or lowcost factors. The inflow of foreign direct investment brings advanced production management experience, 
technology and knowledge innovation to the green development of the region. Hence, market fragmentation hinders the upgrading of industrial structure and the technological progress through FDI, which leads to the non-optimal loss of factor allocation, and affects the relationship between FDI and environmental efficiency.

\section{Robustness Test}

We develop the robustness test to increase the reliability of empirical results. According to the indicators of measuring industrial environmental efficiency, we selected the single-factor efficiency index to evaluate industrial environmental efficiency [48]. In this study, the ratio of $\mathrm{SO}_{2}$ emissions to GDP is used to measure industrial environmental efficiency as an alternative index, which means that the more sulfur dioxide emissions, the lower the environmental efficiency. The results of the effect of alternative proxy on industrial environmental efficiency are presented in Table 4 as a comparison. The results indicate that FDI has negative impact on industrial environmental efficiency. Market fragmentation inhibits the improvement of industrial environmental efficiency. These estimation results are similar to the earlier findings, which show that the empirical results are robust.

\section{Conclusions}

Improving the sustainable development of the industrial sector and achieving industrial energy conservation and emissions reduction have become the focus of attention. Industrial environmental efficiency was selected to measure the sustainable development of industry. We used the super-SBM model to evaluate the industrial environmental efficiency of 29 provinces during 2007-2015 and found that there is still much room for improving industrial environmental efficiency. We selected the relative price method to measure market fragmentation and found that market fragmentation is indeed a serious problem in China. Our study analyzed the impact of FDI and market fragmentation on industrial environmental efficiency based on the system GMM approach. The results indicate that FDI hinders industrial environmental efficiency. Market fragmentation significantly inhibits industrial environmental efficiency. These results are confirmed by a series of robustness tests. We also investigated the effect of the interaction between FDI and market fragmentation on industrial environmental efficiency. The results show that the negative effect of FDI on industrial environmental efficiency is stronger in provinces with more severe market fragmentation.

Based on the above empirical results, our study puts forward the following recommendations. First, the government should eliminate market fragmentation, reduce local protection and promote market integration. On the one hand, the government reduces market intervention, promotes the free flow of factors, and improves the efficiency of factor allocation. On the other hand, the central government should strengthen the punishment of market segmentation, establish a mechanism of market integration, and speed up the integration of regional markets into the national market. Second, the government should continue to attract high-quality foreign investment, actively learn foreign advanced technology and green production processes, and guide FDI to develop high technology and high added value. In addition, the government should also inspect the types and technical levels of FDI and whether it meets environmental standards, and encourage the inflow of high-quality production experience to promote the environmental protection effect of FDI. Third, local governments should improve the innovative ability of resource-intensive utilization and ecological environment management, increase financial and policy support, actively introduce advanced technology and equipment, and build a resource-saving and environment-friendly production system. The government should implement relevant environmental protection measures as soon as possible and urge manufacturing enterprises to strictly abide by environmental laws and regulations in order to optimize an environmentally friendly economic structure, and realize low pollution, low energy consumption and high output.

\section{Acknowledgements}

This study was funded by the National Social Science Fund of China (16AZD002).

\section{Conflict of Interest}

The authors declare no conflict of interest.

\section{References}

1. YANG X., LI C. Industrial environmental efficiency, foreign direct investment and export-Evidence from 30 provinces in China. Journal of Cleaner Production, 212, 1490, 2019.

2. LYU K., BIAN Y., YU A. Environmental efficiency evaluation of industrial sector in China by incorporating learn effects. Journal of Cleaner Production, 172, 2464, 2018.

3. WANG K., YU S., LI M.J., WEI Y.M. Multi-directional efficiency analysis-based regional industrial environmental performance evaluation of China. Natural Hazards, 75, 273, 2015.

4. BLALOCK G., GERTLER, P, J. Welfare gains from foreign direct investment through technology transfer to local suppliers. Journal of International Economics, 74 (2), 402, 2008. 
5. FORSLID R., OKUBO T., ULLTVEIT-MOE K, H. Why are firms that export cleaner? International trade, abatement and environmental emissions. Journal of Environmental Economics and Management, 91, 166, 2018.

6. COLE M. A. Trade, the pollution haven hypothesis and the environmental Kuznets curve: Examining the linkages. Ecological Economics, 48, 71, 2004.

7. SHAHBAZ M., NASREEN S., ABBAS F., ANIS, O. Does foreign direct investment impede environmental quality in high-, middle-, and low-income countries? Energy Economics, 51, 275, 2015.

8. YOUNG A. The razor's edge: Distortions and incremental reform in the people's republic of China. The Quarterly Journal of Economics, 115 (4), 1091, 2000.

9. LIN B., CHEN Z. Does factor market distortion inhibit the green total factor productivity in China? Journal of Cleaner Production, 197, 25, 2018

10. DAI X., CHENG L. Market distortions and aggregate productivity: Evidence from Chinese energy enterprises. Energy Policy, 95, 304, 2016.

11. LIU Y., HAO Y., GAO Y. The environmental consequences of domestic and foreign investment: Evidence from China. Energy Policy, 108, 271, 2017.

12. FRANKEL J., ROMER D. Does trade cause growth? The American Economic Review, 89, 379, 1999.

13. PAO H.T., TSAI C.M. Multivariate granger causality between $\mathrm{CO}_{2}$ emissions, energy consumption, FDI (foreign direct investment) and GDP (gross domestic product): evidence from a panel of BRIC (Brazil, Russian Federation, India, and China) countries. Energy, 36, 685, 2011.

14. KIM H.H., LEE H., LEE J. Technology diffusion and hostcountry productivity in South-South FDI flows. Japan \& The World Economy, 33, 1, 2015.

15. POPP D. International technology transfer, climate change, and the clean development mechanism. Review of Environmental Economics and Policy, 5 (1), 131, 2011.

16. AL-MULALI U., TANG C.F. Investigating the validity of pollution haven hypothesis in the gulf cooperation council (GCC) countries. Energy Policy, 60, 813, 2013.

17. MIELNIK O., GOLDMBERG J. Foreign direct investment and decoupling between energy and gross domestic product in developing countries. Energy Policy, 30, 87, 2002.

18. ZENG K., EASTIN J. Do developing countries invest up? The environmental effects of foreign direct investment from less-developed countries. World Development, 40 (11), 2221, 2012.

19. ZHANG Y., ZHANG S. The impacts of GDP, trade structure, exchange rate and FDI inflows on China's carbon emissions. Energy Policy, 120, 347, 2018.

20. RAFINDADI A.A, MUYE I.M., KAITA R.A. The effects of FDI and energy consumption on environmental pollution in predominantly resource-based economies of the GCC. Sustainable Energy Technologies and Assessments, 25, 126, 2018.

21. REN S., YUAN B., MA X. et al. International trade, FDI (foreign direct investment) and embodied $\mathrm{CO}_{2}$ emissions: A case study of China's industrial sectors. China Economic Review, 28, 123, 2014.

22. SBIA R., SHAHBAZ M., HAMDI H. A contribution of foreign direct investment, clean energy, trade openness, carbon emissions and economic growth to energy demand in UAE. Economic Modelling, 36, 191, 2014.
23. SOLARIN S.A., AL-MULALI U., MUSAH I., OZTURK I., Investigating the pollution haven hypothesis in Ghana: An empirical investigation. Energy, 124, 706, 2017.

24. ZHANG C., ZHOU X. Does foreign direct investment lead to lower $\mathrm{CO} 2$ emissions? Evidence from a regional analysis in China. Renewable and Sustainable Energy Reviews, 58, 943, 2016.

25. JIANG L., ZHOU H.F., BAI L., ZHOU P. Does foreign direct investment drive environmental degradation in China? An empirical study based on air quality index from aspatial perspective. Journal of Cleaner Production, 176, 864, 2018.

26. TANG C.F., TAN B.W. The impact of energy consumption, income and foreign direct investment on carbon dioxide emissions in Vietnam. Energy, 79, 447, 2015.

27. SUN C., ZHANG F., XU M. Investigation of pollution haven hypothesis for China: an ARDL approach with breakpoint unit root tests. Journal of Cleaner Production, 161, 153, 2017.

28. PONCET S. Measuring Chinese domestic and international integration. China Economic Review, 14 (1), $1,2003$.

29. DIEGO R., RICHARD R. Policy distortions and aggregate productivity with heterogeneous plants. Review of Economic Dynamics, 11 (4), 707, 2008.

30. LOREN B., BIESEBROECK J.V. Creative accounting or creative destruction? Firm-level productivity growth in Chinese manufacturing. Journal of Development Economics, 97 (2), 339, 2011.

31. YANG M., YAN F., SUN C. Factor market distortion correction, resource reallocation and potential productivity gains: An empirical study on China's heavy industry sector. Energy Economics, 69, 270, 2018.

32. ZHANG C., ZHANG, Z. Spatial effect of energy resources and technology advance on China's carbon emission intensity. China Population Resources and Environment, 25 (9), 37, 2015.

33. LU M. CHEN Z. Economic growth in market segmentation: Why can economic opening increase local protection? Economic Research Journal, (3), 42, 2009 [In Chinese].

34. CHANG C.P., WEN J., ZHENG M. et al. Is higher government efficiency conducive to improving energy use efficiency? Evidence from OECD countries. Economic Modelling, 72, 65, 2018.

35. ZHANG D., LU Y. Study on the impact of market segmentation on energy efficiency. China Population, Resources and Environment, (1), 65, 2017 [In Chinese].

36. WEI C., ZHENG X. A new perspective of energy efficiency improvement: Based on the test of market segmentation. China Social Science, (10), 91, 2017. [In Chinese]

37. ZHOU L. Incentive and cooperation of government officials in the promotion game: and the reasons for the long-standing problems of local protectionism and repetitive construction in China. Economic Research Journal, (6), 33, 2004 [In Chinese].

38. LI K., LIN B. The nonlinear impacts of industrial structure on China's energy intensity. Energy, 69, 258, 2014.

39. MA M., CAI W., CAI W. Carbon abatement in China's commercial building sector: a bottom-up measurement model based on Kaya-LMDI methods. Energy, 165, 350, 2018.

40. BANKER R.D., CHARNES A., COOPER W.W. Some models for the estimation of technical and scale inefficiencies in data envelopment analysis. Management Science, 30 (9), 1078, 1984. 
41. GOMEZ-CALVET R., CONESA D., GOMEZ-CALVET A.R., TORTOSA-AUSINA E. Energy efficiency in the European Union: what can be learned from the joint application of directional distance functions and slacksbased measures. Applied Energy, 132, 137, 2014.

42. TONE K. A slacks-based measure of efficiency in data envelopment analysis. European Journal of Operational Research, 130 (3), 498, 2001.

43. CHARNES A., COOPER W.W. Programming with linear fractional functionals. Naval Research Logistics, 9, 181, 1963.

44. LI C., YUAN B., ZHANG Y. Effect assessment of ecological construction in china from 2008 to 2014. Polish Journal of Environmental Studies, 28, 1, 2019.
45. PARSLEY D.C., WEI S.J. Limiting currency volatility to stimulate goods market integration: A price based approach. National Bureau of Economic Research Working Paper Series, No. 8468, 2001.

46. BLUNDELL R., BOND S. Initial conditions and moment restrictions in dynamic panel data model. Journal of Econometrics, 87, 115, 1998.

47. CHEN M., GUARIGLIA, A. Internal financial constraints and firm productivity in China: Do liquidity and export behavior make a difference?. Journal of Comparative Economics, 41 (4), 1123, 2013.

48. LIN B., TAN R. Ecological total-factor energy efficiency of China's energy intensive industries. Ecological Indicators, 70, 480, 2016. 